\title{
Sarkoidozlu Hastalarda Sistolik Pulmoner Arter Basıncının Pulmoner Arter Çapı, Yaş, Hastalık Süresi, Hastalığın Evresi ve Akciğer Dışı Tutulumla İlişskisi
}

\section{The Association of Systolic Pulmonary Artery Pressure with Pulmonary Artery Diameter, Age, Disease Duration, Stage of the Disease, and Extrapulmonary Involvement in Patients with Sarcoidosis}

\author{
${ }^{1}$ Celalettin KORKMAZ, ${ }^{1}$ Soner DEMIRBAS, ${ }^{1}$ Hulya VATANSEV \\ ${ }^{1}$ Necmettin Erbakan University, Meram Medical School, Department of Chest Diseases, Konya, Turkey \\ Celalettin Korkmaz: https://orcid.org/0000-0001-8602-0368 \\ Soner Demirbas: https://orcid.org/0000-0002-9072-0217 \\ Hulya Vatansev: https://orcid.org/0000-0002-8382-3904
}

\begin{abstract}
ÖZ
Amaç: Sarkoidozlu hastalarda sistolik pulmoner arter basıncının (sPAB) pulmoner arter çapı (PAÇ), yaş, cinsiyet, hastalık süresi, hastalığın evresi, akciğer dışı tutulum ve spontan remisyon ile olan ilişkilerini araştırmayı amaçladik.

Materyal ve Metot: Çalışmaya göğüs hastalıkları kliniğinde 2010-2020 yılları arasında tanı almış ve takip edilmiş 60 sarkoidozlu hasta alındı. Hastaların demografik verileri, klinik seyri, tedavi bilgileri radyolojik ve ekokardiyografik incelemeleri kaydedildi. EKO'ya dayal ortalama PAB'nın hesaplanmasında sPAB kullanıldı. PAÇ toraks BT konusunda yetkin radyolog tarafindan ölçüldü. $\mathrm{PAB}$ ile PAÇ ve diğer parametreler arasındaki ilişki araştırild1.

Bulgular: Hastaların sPAB: $29,68 \pm 5,73 \mathrm{mmHg}$, PAÇ: $28,20 \pm 5,75 \mathrm{~mm}$ olarak bulundu. Aralarında anlamlı korelasyon saptand $1(\mathrm{r}=0,46 \mathrm{p}<0,001)$. PAÇ, PH'u olan hastalarda: $39,7 \pm 4,6$, olmayanlarda: $27 \pm 4,9 \quad(\mathrm{p}<0,001)$ idi. sPAB, ekstrapulmoner tutulumu olmayanlarda $31,03 \pm 6,35$, olanlarda: $27,52 \pm 3,77 \quad(p=0,01)$ bulundu. Araştırılan diğer parametrelerle anlamlı ilişki saptanmadı. Sonuç: Sarkoidozlu hastalarda $\mathrm{SPAB}$ ve PAÇ arasında orta derecede kuvvetli pozitif yönlü korelasyon saptand1. Aynı zamanda PAÇ, PH olan hastalarda olmayanlara göre anlamlı olarak daha yüksek bulundu. Bu da sarkoidozlu hastalarda toraks BT incelemesi esnasında kolaylıkla ölçülebilen PAÇ'nın sarkoidozla ilişkili pulmoner hipertansiyonu (SIPH) tahmin etmede yol gösterici olabileceğini göstermektedir.
\end{abstract}

Anahtar Kelimeler: Pulmoner arter çapı, pulmoner hipertansiyon, sarkoidoz, sistolik pulmoner arter basinc1

\section{ABSTRACT}

Objective: We aimed to investigate the association of systolic pulmonary artery pressure (sPAP), with pulmonary artery diameter (PAD), age, gender, disease duration, disease stages, extrapulmonary involvement, and spontaneous remission in patients with sarcoidosis.

Materials and Methods: Diagnosed and followed-up in the chest diseases clinic between 2010-2020, 60 sarcoidosis patients were included. Patients' demographic data, clinical course, information over treatment, radiological and echocardiographic examinations were recorded. $\mathrm{sPAB}$ was utilized to calculate mean PAP based on ECHO. PAD was measured by an experienced radiologist in thoracic $\mathrm{CT}$. Associatons of PAP and PAD with other parameters were investigated.

Results: SPAP and PAD were found as $29.68 \pm 5.73 \mathrm{mmHg}$ and $28.20 \pm 5.75 \mathrm{~mm}$. A significant correlation was detected between them $(\mathrm{r}=0.46 \mathrm{p}<0.001)$. PADs were $39.7 \pm 4.6$ and $27 \pm 4.9$ in patients with and without $\mathrm{PH}$ $(\mathrm{p}<0.001)$. sPAPs were found as $27.52 \pm 3.77$ and $31.03 \pm 6.35$ among those with and without extrapulmonary involvement $(\mathrm{p}=0.01)$. No association was found between these parameters and others.

Conclusion: A moderately strong positive correlation was detected between SPAP and PAD in sarcoidosis patients. $\mathrm{PAD}$ was significantly found higher in patients with $\mathrm{PH}$ than those without. This also shows that PAD, which can be easily measured during thoracic CT examination in sarcoidosis patients, can be a guide in predicting sarcoidosis-associated pulmonary hypertension (SAPH).

Keywords: Pulmonary hypertension, pulmonary artery diameter, sarcoidosis, systolic pulmonary artery pressure

\section{Sorumlu Yazar / Corresponding Author:}

Celalettin Korkmaz

Necmettin Erbakan Üniversitesi, Meram Tıp Fakültesi Hastanesi, Hocacihan mah. Abdulhamid Han cad. No:3 42080 Selçuklu, Konya, TURKEY

Tel: +905054350731

E-mail: celalettinkorkmaz@hotmail.com
Yayın Bilgisi / Article Info:

Gönderi Tarihi/ Received: 22/12/2020

Kabul Tarihi/ Accepted: 10/01/2021

Online Yayın Tarihi/ Published: 05/03/2021

Atıf / Cited: Korkmaz C, et al. The Association of Systolic Pulmonary Artery Pressure with Pulmonary Artery Diameter, Age, Disease Duration, Stage of the Disease, and Extrapulmonary Involvement in Patients with Sarcoidosis. Online Türk Sağllk Bilimleri Dergisi 2021;6 (1):22-30. doi: 10.26453 /otjhs.845321 


\section{INTRODUCTION}

As an inflammatory disease of unknown cause, sarcoidosis is characterized by the formation of granulomas in the affected organs, mostly in the lungs. The disease develops in genetically susceptible individuals through the exposure to an unknown antigen as yet. ${ }^{1}$ Pulmonary hypertension $(\mathrm{PH})$, defined as the mean pulmonary artery pressure (PAP) of $\geq 25$ $\mathrm{mmHg}^{2}$ by right heart catheterization (RHC), is a well-known complication of sarcoidosis and associated with a significant increase in mortality. ${ }^{3}$ However, echocardiography (ECHO) is used as an important device in the assessment of sarcoidosisrelated pulmonary hypertension (SAPH). ${ }^{4}$ Pulmonary hypertension $(\mathrm{PH})$ is a fearful complication in patients with sarcoidosis since it is an important negative prognostic factor for lung transplantation to be required in these patients at an advanced stage. ${ }^{5}$ $\mathrm{PH}$ is considered to be a vasculopathy caused by the excessive growth of vascular cells along with inflammation playing a major role in the process. ${ }^{6}$

SAPH is witnessed in 5 to $20 \%$ of sarcoidosis patients. Increased PAP may be due to comorbidities such as cardiac sarcoidosis and sleep apnea, as well as many factors such as vasculocentric, parenchymal, and mechanical effects. Fibrotic lung disease is encountered in most patients with SAPH; however, SAPH may also be seen in those without advanced parenchymal lung disease. In sarcoidosis, while PH is often associated with pulmonary fibrosis, a recent multinational study has reported that almost $25 \%$ of $\mathrm{PH}$ cases associated with sarcoidosis were radiological stages 2 and $3,{ }^{7}$ suggesting that $\mathrm{PH}$ is of a multifactorial mechanism. In two recent studies conducted in two major reference centers and investigating the predictors of mortality in pulmonary sarcoidosis, high-resolution computerized tomography (HRCT) showed that more than $20 \%$ of pulmonary fibrosis and $\mathrm{PH}$ are independent predictive factors of mortality. ${ }^{8,9}$ In another international study performed with the same purpose, systolic pulmonary artery pressure (sPAP), carbon monoxide diffusing capacity (CMDC), and 6-minute walking distance (6MWD) were demonstrated to be statistically significant predictors of transplant-free survival in patients with SAPH. ${ }^{7}$

In our study, we aimed to investigate the association between sPAP, so important for sarcoidosis patients, and pulmonary artery diameter (PAD), age, disease duration, stages of the disease, and extrapulmonary involvement.

\section{MATERIALS AND METHODS}

The present study was performed by following under the Declaration of Helsinki Good Clinical Practice Guidelines in 1964 and later amendments and approved by the Ethics Committee of the Medical Faculty of Necmettin Erbakan University (Date: 04/12/2020, decision no: 2020/2930). In the study, 110 sarcoidosis patients were diagnosed and followed-up clinically, radiologically, and histopathologically in the department of chest diseases between 2010 and 2020 . The data related to all sarcoidosis patients over 18 years of age were obtained by scanning the patients' files and from the hospital information management system. Thirtytwo patients due to exclusion criteria and 18 patients due to missing follow-up data were excluded from the study. Therefore, 60 patients with sarcoidosis completed the study. The patients with any metabolic disease, any type of cancers, rheumatological disease, vasculitis, inflammatory bowel disease, hematological disease, autoimmune disease, and those with cardiovascular disease or other pulmonary diseases other than the cardiac involvement of sarcoidosis were not included in the study.

In the study, sarcoidosis was diagnosed by demonstrating the epithelioid cell granulomas histopathologically without caseous necrosis in biopsies taken by the endobronchial ultrasound-guided transbronchial needle aspiration biopsy (EBUS-TBNA) and mediastinoscopic methods in the company with clinical and radiological findings, and by ruling out other causes of granulomatous inflammation. ${ }^{10}$

The features such as patients' age and gender, results of thoracic computerized tomography (CT) and HRCT, stages sarcoidosis at the time of diagnosis, results of ECHO, the data, and findings after consultations about extrapulmonary involvement, the treatment modalities, and the history of patients' clinical course and epicrisis reports were recorded. Sarcoidosis patients were staged as follows: Those with normal chest radiology as stage-0, those with hilar LAPs as stage-1, those with parenchymal involvement, and hilar LAPs as stage-2, those with only parenchymal involvement as stage- 3 , and those with pulmonary fibrosis as stage- $4 .{ }^{11}$ The method used to diagnose PH definitely is RHC. ${ }^{4}$ However, we used the systolic PAP (sPAP) as the basis to calculate the mean PAP based on ECHO (mean $\mathrm{PAP}=0.61 \mathrm{xsPAP}+2 \mathrm{mmHg}){ }^{12}$ since our study was 
retrospectively designed and the patients' RHC measurements were not performed. While the mean PAP was accepted as $\geq 25 \mathrm{mmHg} \mathrm{PH}, \mathrm{PAD}$ was also measured at the bifurcation level along the line from the center of the adjacent ascending aorta perpendicular to the axis of the main pulmonary artery by a radiologist with expertise in thoracic $\mathrm{CT} .{ }^{13}$ The measurements of PAD were performed through thoracic $\mathrm{CT}$ taken simultaneously with ECHO. In our study, the associations between SPAP, and PAD, age, gender, disease duration, stages of the disease, extrapulmonary involvement, and spontaneous remission were investigated.

Statistical analysis: Statistical analyses of the study findings were evaluated with the Statistical Package for the Social Sciences software, version 24.0 (SPSS Inc., Chicago, IL, USA). The analyses were performed for the appropriateness of normal distribution. In terms of the correlations, while the variables with normal distribution were assessed with the Pearson correlation test, those with no normal distribution were measured using the Spearman correlation test. The student T-test was used for the inter-group comparisons. The Mann-Whitney U test was used for two-group comparisons without normal distributions. The Kruskal Wallis test was performed for the variables in multi-group comparisons, In all analyzes, a $p$-value of $<0.05$ was accepted to be significant.

\section{RESULTS}

The patients' average age was found as $56.45 \pm 14.75$ years. Of 60 sarcoidosis patients, 46 were female, and 14 were male (Table 1). While the mean sPAP values of our patients were found to be $29.68 \pm 5.73$ mmHg (min-max: 22 and 45), the mean PAD was also detected as $28.20 \pm 5.75 \mathrm{~mm}$ (min-max: 19 and 46) (Table 2).

A moderately powerful positive correlation was found between sPAP and PAD $(r=0.46, p<0.001)$. There were seven (11.7\%) PH patients with a mean PAP of $\geq 25 \mathrm{mmHg}$. PAD was found to be statistically significantly higher in patients with $\mathrm{PH}$ $(\mathrm{p}<0.001)$ (Table 3).

The mean sPAP of female patients was determined as $30 \pm 6.24 \mathrm{mmHg}$, while male patients' mean sPAP was $28.64 \pm 3.62 \mathrm{mmHg}(\mathrm{p}=0.44)$, and there was no statistically significant difference between both genders' sPAP values.

The mean PAD in female patients was $28 \pm 5.46 \mathrm{~mm}$, and the mean PAD among male patients was detected as $28.86 \pm 6.79(\mathrm{p}=0.62)$. There was no statistically significant difference between the PAD values of both genders.

In our study, it was also investigated whether there was a correlation between the patients' age, and sPAP and PAD; however, no significant correlation was found [for PAP $(r=0.15, p=0.22)$ and PAD $(\mathrm{r}=0.21, \mathrm{p}=0.09)]$.

Although there was no extrapulmonary involvement in $37(61.7 \%)$ of our patients, various involvements were determined in 23 patients as follows: Skin in seven patients at most, cardiac in six, Löfgren syndrome in five, Heerfordt syndrome in two, eye in one, kidney in one, and rectum in one patient ( $\underline{\text { Table }}$ 1).

The values of sPAP were seen to be significantly higher in patients without extrapulmonary involvement than those with extrapulmonary involvement $(31.03 \pm 6.35$ and $27.52 \pm 3.77, \mathrm{p}=0.01)$. None of seven patients determined to have PH had extrapulmonary involvement. Compared the patients with and without extrapulmonary involvements in terms of PAD, the values were slightly higher in those without extrapulmonary involvement (28.81 \pm 5.4 and 27.22 \pm 6.15 ); however, the difference was not statistically significant.

The mean disease duration of our sarcoidosis patients was found as $4.06 \pm 2.79$, and it was investigated whether there was a correlation between disease duration, and SPAP and PAD. Even so, no significant correlation was found [for $\mathrm{SPAP}(\mathrm{r}=$ 0.007, $\mathrm{p}=0.95)$ and for PAD $(\mathrm{r}=0.06, \mathrm{p}=0.6)]$.

When the values of SPAP and PAD were compared in terms of the stages of the disease, no significant difference was found between SPAP and PAD values ( $p=0.25$ for $\mathrm{sPAP}$ and $\mathrm{p}=0.28$ for $\mathrm{PAD}$ ).

Compared sarcoidosis patients with and without spontaneous remission, no significant difference was found between those with and without spontaneous remission (for $\mathrm{sPAP} p=0.25$ and $\mathrm{PAD} \mathrm{p}=0.55$ ).

Of our 60 patients, 28 (46.6\%) were determined to be administered with the systemic steroid therapy due to the indications. While two patients were treated with the combination of methotrexate and prednisolone, two patients and one patient were detected to receive the treatments with non-steroidal anti-inflammatory drugs (NSAIDs) and infliximab, respectively (Table 1). Given the measurements of one stage- 4 patient (sPAP, 45-55 $\mathrm{mmHg}$ before and after treatment) and three stage- 2 patients (sPAP values, 43-47, 45-37, and 40-35 $\mathrm{mmHg}$ before and after treatment) among those with $\mathrm{PH}$, no significant difference was determined. 
However, when the patients receiving systemic steroid treatment (methylprednisolone) were compared with those who did not, sPAB values were measured as $28.5 \pm 5.58 \mathrm{mmHg}$ among those receiving systemic steroid treatment and $30.59 \pm 5.69$ $\mathrm{mmHg}$ in those not receiving the treatment, and there was no significant difference between these two groups. No significant difference was also found between those receiving systemic steroids and those who did not in terms of PAD values (27.96 \pm 6.3 in those receiving the treatment, and $28.88 \pm 5.37$ in those who did not)

\section{DISCUSSION AND CONCLUSION}

In our study, a moderately powerful positive significant correlation was determined between SPAP and PAD. The values of PAD was also found to be statistically significantly higher among the patients with $\mathrm{PH}$. These findings suggest that PAD, which can be easily measured in examining thoracic CT in sarcoidosis patients, can be a guide in predicting SAPH.

In the study where PAD was similarly investigated to predict $\mathrm{PH}$ in pulmonary sarcoidosis, Huitema et al. also suggested that the diameter of PA indexed to the body surface area (BSA) is a reliable predictor of $\mathrm{PH}$ in the patients with pulmonary sarcoidosis, and thus reported that the measurement of $\mathrm{PA}$ on thoracic $\mathrm{CT}$ may be valuable in pulmonary sarcoidosis. $^{14}$

In our study, sPAP was found to be significantly higher in those without extrapulmonary involvement ( $31.03 \pm 6.35$ and $27.52 \pm 3.77, p=0.01)$. Considering the patients with extrapulmonary involvement, however, the fact that SPAP was found to be significantly lower suggests that $\mathrm{PH}$, which is a predictor of poor prognosis in the condition, is less commonly seen in this disease, and this can also be used to predict the good prognosis.

Although the first case of $\mathrm{PH}$ in sarcoidosis was described in $1949,{ }^{15}$ its exact prevalence remains unclear. Three previous studies of great importance in the field reported that the prevalences of $\mathrm{PH}$ were $5,7 \%, 14 \%$, and $20.8 \%{ }^{16-18}$ In these studies, the right ventricular systolic pressure (RVSP) was based to be $\geq 40 \mathrm{mmHg}$ on the diagnosis of $\mathrm{PH}$ (if there is no significant stenosis in the right ventricular orifice or pulmonary valve, RVSP is equivalent to SPAP). Similarly, the prevalence of $\mathrm{PH}$ was also found to be $11.7 \%$ in our patients. In the current Pulmonary Hypertension in Sarcoidosis (PULSAR) study, the prevalence of $\mathrm{PH}$ was found as $3 \%$ in predominantly
Caucasian-originated individuals consisting of 400 sarcoidosis patients using ECHO, and if indicated RCC, and it was reported in the study that ethnic differences may play a role in the prevalence of $\mathrm{PH}^{19}$

In a previous important study, $\mathrm{PH}$ was suggested to be associated with the prevalence of stage- 4 parenchymal disease. ${ }^{20}$ In this study, while $60 \%$ of those with $\mathrm{PH}$ were seen to be stage- 4 patients, another stage was not observed as prominent among those without pulmonary HT. In the study investigating the same entity and performed by Shlobin et al. as one of the latest multinational studies, it has been reported that $65.6 \%$ of the patients with $\mathrm{PH}$ had stage- 4 diseases, and only $2 \%$ were stage- 1 patients ${ }^{7}$. Of seven patients with SAPH in our study, four were stage-2 patients, two were stage-1, and only one patient was at stage- 4 . Even so, when all patients were compared in terms of sPAP and PAD according to the stages, no significant difference was found between both groups.

Although a response rate between $20-30 \%$ has been reported in small series treated with antiinflammatory drugs in SAPH, the treatment with anti-inflammatory drugs has shown no consistent benefit ${ }^{21}$. In neither the International Registry for Sarcoidosis Associated Pulmonary Hypertension $(\operatorname{ReSAPH})^{7}$ nor the large-scale French study ${ }^{3}$, the steroid treatment was not associated with better results. In our study, no significant difference was found between the measurements of sPAP before and after the treatment in our patients with $\mathrm{PH}$. Besides, whether there was a significant difference was also investigated in sarcoidosis patients with and without spontaneous remission in terms of sPAP and PAD. Compared sarcoidosis patients with and without spontaneous remission, no significant difference was found between those with and without spontaneous remission.

In our study, no significant difference was found between the female and male patients in terms of sPAP and PAD. Additionally, there was no significant correlation between the patients' age and disease duration, and SPAP and PAD.

Limitations of the study: Our study has also some limitations. One of the important limitations is that PH could not be demonstrated by RHC. Besides, our study was performed in a single-center, and the number of our study participants is limited. So, we consider our findings cannot be generalized.

In conclusion, there is a moderately powerful posi- 
tive correlation between SPAP and PAD in the patients with sarcoidosis, and PAD was also found to be significantly higher in the patients with $\mathrm{PH}$ than those without. This also reveals that PAD, which can be easily measured during the examination of thoracic $\mathrm{CT}$ in sarcoidosis patients, can be used as a guide in predicting SAPH. For this reason, we consider that more comprehensive prospective studies including RHC are needed to elucidate the relationship of PAD and PAP.

Ethics Committee Approval: The study was approved by the Ethics Committee of the Medical Faculty of Necmettin Erbakan University (Date: 04/12/2020, decision no: 2020/2930).

Conflict of Interest: No conflict of interest was declared by the authors.

Author Contributions: Concept - CK, SD; Supervision - CK, HV; Materials - CK, SD; Data Collection and/or Processing - CK, HV; Analysis and/ or Interpretation - CK, SD; Writing - CK

Peer-review: Externally peer-reviewed.

Acknowledgment: Authors thank Cengiz Kadiyoran for the measurements of pulmonary artery diameter and Numan Duran for language editing

\section{REFERENCES}

1. Grunewald J, Grutters JC, Arkema EV, Saketkoo LA, Moller DR, Müller-Quernheim J. Sarcoidosis. Nat Rev Dis Primers. 2019;5(1):45. doi:10.1038/s41572-019-0096-x.

2. Galie N, Humbert M, Vachiery JL, et al. 2015 ESC/ERS Guidelines for the diagnosis and treatment of pulmonary hypertension. The joint task force for the diagnosis and treatment of pulmonary hypertension of the European Society of Cardiology (ESC) and the European Respiratory Society (ERS). Eur Respir J. 2015;46(6):18551856. doi: 10.1183/13993003.51032-2015

3. Boucly A, Cottin V, Nunes H, et al. Management and long-term outcomes of sarcoidosisassociated pulmonary hypertension. Eur Respir J. 2017;50(4):1-12.

4. Shlobin OA, Baughman RP. Sarcoidosisassociated pulmonary hypertension. Semin Respir Crit Care Med. 2017;38(4):450-462.

5. Baughman RP, Engel PJ, Meyer CA, Barrett AB, Lower EE. Pulmonary hypertension in sarcoidosis. Sarcoidosis Vasc Diffuse Lung Dis. 2006;23 (2):108-116.
6. Baughman RP. Pulmonary hypertension associated with sarcoidosis. Arthritis Res Ther. 2007;9 (Suppl 2):S8. doi: 10.1186/ar2192

7. Shlobin OA, Kouranos V, Barnett SD, et al. Physiological predictors of survival in patients with sarcoidosis-associated pulmonary hypertension: results from an international registry. Eur Respir J. 2020;55(5):1-28.

8. Walsh SL, Wells AU, Sverzellati N, et al. An integrated clinicoradiological staging system for pulmonary sarcoidosis: a case-cohort study. Lancet Respir Med. 2014;2(2):123-130.

9. Kirkil G, Lower EE, Baughman RP. Predictors of mortality in pulmonary sarcoidosis. Chest. 2018;153(1):105-113.

10. Judson MA, Costabel U, Drent M, et al. The WASOG Sarcoidosis organ assessment instrument: An update of a previous clinical tool. Sarcoidosis Vasc Diffuse Lung Dis. 2014;31(1):1927.

11. Greco FG, Spagnolo P, Muri M, et al. The value of chest radiograph and computed tomography in pulmonary sarcoidosis. Sarcoidosis Vasc Diffuse Lung Dis. 2014;31(2):108-116.

12. Runo JR, Vnencak-Jones CL, Prince M, et al. Pulmonary veno-occlusive disease caused by an inherited mutation in bone morphogenetic protein receptor II. Am J Respir Crit Care Med. 2003;167(6):889-894.

13. Mahammedi A, Oshmyansky A, Hassoun PM, Thiemann DR, Siegelman SS. Pulmonary artery measurements in pulmonary hypertension: the role of computed tomography. J Thorac Imaging. 2013;28(2):96-103.

14. Huitema MP, Spee M, Vorselaars VM, et al. Pulmonary artery diameter to predict pulmonary hypertension in pulmonary sarcoidosis. European Respiratory Journal. 2016;47(2):673-676.

15.Zimmerman I, Mann N. Boeck's sarcoid: a case of sarcoidosis complicated by pulmonary emphysema and cor pulmonale. Annals of internal medicine. 1949;31(1):153-162.

16. Handa T, Nagai S, Miki S, et al. Incidence of pulmonary hypertension and its clinical relevance in patients with sarcoidosis. Chest. 2006;129 (5):1246-1252.

17. Bourbonnais JM, Samavati L. Clinical predictors of pulmonary hypertension in sarcoidosis. Eur Respir J. 2008;32(2):296-302.

18. Alhamad EH, Idrees MM, Alanezi MO, Alboukai AA, Shaik SA. Sarcoidosis-associated pulmonary 
hypertension: Clinical features and outcomes in Arab patients. Ann Thorac Med. 2010;5(2):8691.

19. Huitema MP, Bakker ALM, Mager JJ, et al. Prevalence of pulmonary hypertension in pulmonary sarcoidosis: the first large European prospective study. Eur Respir J. 2019;54(4):1-4.

20. Sulica R, Teirstein AS, Kakarla S, Nemani N, Behnegar A, Padilla ML. Distinctive clinical, radiographic, and functional characteristics of patients with sarcoidosis-related pulmonary hypertension. Chest. 2005;128(3):1483-1489.

21. Rodman DM, Lindenfeld J. Successful treatment of sarcoidosis-associated pulmonary hypertension with corticosteroids. Chest. 1990;97(2):500-502. 
Table 1. Demographic and clinical characteristics.

\begin{tabular}{|c|c|c|c|}
\hline \multirow[t]{2}{*}{ Age } & \multicolumn{3}{|l|}{$56.45 \pm 14.75$} \\
\hline & & $\mathbf{N}$ & $\%$ \\
\hline \multirow[t]{2}{*}{ Gender } & Female & 46 & 77 \\
\hline & Male & 14 & 23 \\
\hline \multirow{4}{*}{$\begin{array}{l}\text { The stages of the } \\
\text { disease }\end{array}$} & Stage 1 & 21 & 35 \\
\hline & Stage 2 & 34 & 57 \\
\hline & Stage 3 & 4 & 6 \\
\hline & Stage 4 & 1 & 2 \\
\hline \multirow{8}{*}{$\begin{array}{l}\text { Extrapulmonary } \\
\text { Involvement }\end{array}$} & No & 37 & 61.7 \\
\hline & Skin & 7 & 11.7 \\
\hline & Heart & 6 & 10.0 \\
\hline & Löfgren syndrome & 5 & 8.3 \\
\hline & Heerfordt syndrome & 2 & 3.4 \\
\hline & Eyes & 1 & 1.7 \\
\hline & Kidneys & 1 & 1.7 \\
\hline & Rectum & 1 & 1.7 \\
\hline \multirow{5}{*}{$\begin{array}{l}\text { Medications used } \\
\text { for treatment }\end{array}$} & No (follow-up without medications) & 29 & 48.3 \\
\hline & Methylprednisolone & 26 & 43.3 \\
\hline & Methylprednisolone + methotrexate & 2 & 3.3 \\
\hline & NSAIDs & 2 & 3.3 \\
\hline & Infliximab & 1 & 1.7 \\
\hline
\end{tabular}

N: Number of patients, NSAIDs: Non-steroidal anti-inflammatory drugs. 
Table 2. Association between systolic pulmonary artery pressure and pulmonary artery diameter.

\begin{tabular}{|l|c|c|c|c|c|}
\hline & N & Mean \pm SD & Min-Max & r & p \\
\cline { 1 - 4 } sPAP $(\mathrm{mmHg})$ & 60 & $29.68 \pm 5.73$ & $22-45$ & 0.46 & $<0.001$ \\
\cline { 1 - 4 } PAD $(\mathrm{mm})$ & 60 & $28.20 \pm 5.75$ & $19-46$ & & \\
\hline
\end{tabular}

Min-Max: Minimum and maximum values; N: Number of patients; PAD: Pulmonary artery diameter; SD: Standard deviation; sPAP: Systolic pulmonary artery pressure; r: Correlation coefficient. 
Table 3. Comparison of PAD between both groups with and without $\mathrm{PH}$.

\begin{tabular}{|l|c|c|c|c|c|}
\hline & $\begin{array}{c}\text { PAP } \\
\text { Mean } \pm \text { SD }\end{array}$ & $\begin{array}{c}\text { PAD } \\
\text { Mean } \pm \text { SD }\end{array}$ & $\begin{array}{c}\text { PAP } \\
\text { Median (Min- } \\
\text { Max) }\end{array}$ & $\begin{array}{c}\text { PAD } \\
\text { Median (Min- } \\
\text { Max) }\end{array}$ & $*$ * \\
\cline { 1 - 5 } $\begin{array}{l}\text { Patients with PH } \\
(\mathbf{n}=7)\end{array}$ & $27.3 \pm 1.9$ & $39.7 \pm 4.6$ & $28(25-29)$ & $38(28-41)$ & \multirow{2}{*}{$<0.001$} \\
\cline { 1 - 2 } & $19 \pm 2.9$ & $27 \pm 4.9$ & $19(15-29)$ & $26(19-46)$ & \\
PH (n=53)
\end{tabular}

Min-Max: Minimum and maximum values; PAD: Pulmonary artery diameter,; PAP: Pulmonary artery pressure; PH: Pulmonary hypertension; SD: Standard deviation; *A p value is $\mathrm{p}<0.001$ for mean and median values. 